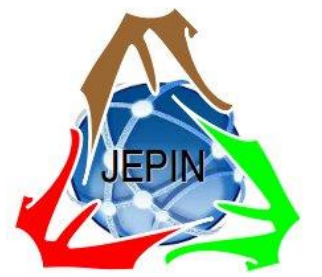

\title{
Sistem Informasi Monitoring dan Evaluasi dengan Menggunakan Kurva S sebagai Indikator Realisasi dan Kemajuan Pekerjaan
}

\author{
Yulrio Brianorman ${ }^{\# 1}$, Waspodo ${ }^{* 2}$

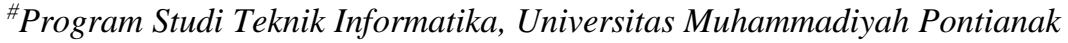 \\ Jl. Jenderal Ahmad Yani No.111, Pontianak 78123 \\ ${ }^{1} \mathrm{y} \cdot \mathrm{brianormaneunmuhpnk}$. ac.id \\ *Program Studi Teknik Mesin, Universitas Muhammadiyah Pontianak \\ Jl. Jenderal Ahmad Yani No.111, Pontianak 78123 \\ ${ }^{2}$ waspodo@unmuhpnk.ac.id
}

\begin{abstract}
Abstrak - Upaya monitoring dan evaluasi terhadap suatu proyek pekerjaan pada dinas di pemerintahan merupakan hal penting untuk mengetahui proses serta status kemajuan pekerjaan dengan cepat dan akurat. Proses ini menjadi indikator utama keberhasilan suatu pekerjaan. Sistem informasi yang dibangun ini mencakup monitoring dan evaluasi pada pekerjaan fisik serta pada proses pembayaran keuangan pekerjaan. Indikator kemajuan pekerjaan fisik menggunakan kurva $S$ yang dapat menggambarkan kemajuan volume pekerjaan yang diselesaikan. Sementara monitoring dan evaluasi keuangan dilakukan pencatatan secara mendetail. Penelitian menghasilkan aplikasi sistem monitoring dan evaluasi pekerjaan yang memberikan informasi mengenai kemajuan pekerjaan baik pada bagian pengerjaan fisik maupun proses keuangan. Sistem ini telah diujicobakan di Bidang SDA Dinas Pekerjaan Umum Kabupaten Kuburaya menggunakan 2 pengujian yaitu blackbox dan User Acceptance Test (UAT). Hasil pengujian blackbox menunjukkan bahwa semua fitur yang dibangun dapat bekerja dengan baik. User Acceptance Test (UAT) sebesar $75 \%$ menunjukkan user sangat menyetujui bahwa sistem ini sesuai kebutuhan bisnis dan layak untuk digunakan. Responden terdiri dari 4 orang ASN dari bidang SDA pada Dinas PUPR Kabupaten Kuburaya.
\end{abstract}

Kata kunci - Sistem Informasi, Monitoring, Evaluasi, Kurva S, Pekerjaan Dinas, User Acceptance Test.

\section{Pendahuluan}

Dinas Pekerjaan Umum merupakan salah satu instansi pemerintah yang bertanggungjawab atas segala hal yang berkaitan dengan bidang pembangunan di Indonesia, satu di antaranya adalah Dinas Pekerjaan Umum di kabupaten Kuburaya. Kabupaten Kuburaya memiliki luas wilayah $6.958 \mathrm{Km}^{2}$ dan memiliki 9 kecamatan. Pada Dinas Pekerjaan Umum kabupaten Kuburaya terdapat bidang Sumber Daya Air. Bidang ini menyediakan sarana prasarana seperti drainase, pengairan, saluran irigasi dan fisik umum lainnya yang terkait. Selama ini kendala yang dihadapi oleh Bidang SDA Dinas PU Kabupaten Kuburaya adalah melakukan monitoring dan evaluasi terhadap pekerjaan yang sedang dilaksanakan. Kendala ini terjadi disebabkan luasnya wilayah, penyebaran pekerjaan ke berbagai wilayah dan volume pekerjaan yang besar.

Monitoring dan evaluasi pekerjaan merupakan indikator utama keberhasilan suatu pekerjaan. Penerapan teknologi pada sistem pelaporan elektornik yang disebut dengan istilah e-monitoring merupakan pemantauan dan pelaporan melalui media internet yang dapat dilihat dan diketahui dari mana saja dan kapan saja. Aplikasi e-monitoring sudah banyak digunakan di instansi pemerintahan pemerintahan di antaranya e-Monitoring Dana Alokasi Khusus Kementrian PUPR dan Monitoring dan Evaluasi Program Kerja Kementerian Perhubungan. Proses monitoring dan evaluasi yang dilakukan pada awalnya dilakukan dengan cara penyampaian laporan mingguan oleh para konsultan pengawas berupa hasil cetak laporan atau email kepada pejabat pengawas. Dengan proses ini muncul kendala yang dihadapi seperti bentuk laporan yang tidak memiliki format yang seragam, keterlambatan penyampaian laporan, sulitnya akses ke lokasi pekerjaan yang berada di pelosok daerah, perbedaan antara data laporan yang diterima dengan kondisi di lapangan, serta data yang sulit dikumpulkan ataupun dicari.

Pada Tabel 1 terlihat jumlah Pekerjaan dan Total Nilai Pekerjaan yang dimiliki bidang SDA pada Dinas PUPR Kabupaten Kuburaya pada tahun 2018 dan 2019.

TABEL

DATA PEKERJAAN DAN TOTAL NILAI PEKERJAAN

\begin{tabular}{|c|c|c|}
\hline Tahun & Pekerjaan & Nilai Pekerjaan \\
\hline 2018 & 127 & Rp. 40.439.930.000,- \\
\hline 2019 & 125 & Rp. $28.247 .500 .000,-$ \\
\hline
\end{tabular}

Permasalahan tersebut di atas mengakibatkan proses monitoring dan evaluasi pekerjaan pada bidang Sumber 
Daya Air menjadi terhambat. Hal inilah yang menjadi landasan berpikir untuk melakukan penelitian mengenai proses dan metode monitoring dan evaluasi yang nanti akan digunakan untuk membangun sistem monitoring dan evaluasi yang berbasis pada elektronik. Selain permasalahan yang telah disebutkan proses monitoring dan evaluasi ini juga terkait pada dalam rangka pelaksanaan Peraturan Pemerintah Nomor 8 Tahun 2008 tentang Tahapan, Tata Cara Penyusunan, Pengendalian dan Evaluasi Pelaksanaan Perencanaan Pembangunan Daerah [1].

Sistem yang dibangun ini diharapkan dapat mengolah data informasi pelaporan secara teratur, tepat waktu, lengkap dan faktual. Sistem ini memuat pengelolaan rencana dan kemajuan pekerjaan yang dapat di perbaharui oleh tim pejabat pengawas lapangan dari laporan yang diterima. Sistem ini juga dirancang untuk memuat pelaporan penyerapan keuangan, melampirkan foto fisik pembangunan dengan persentase pencapaiannya yang mengacu kepada rencana yang menggunakan mekanisme kurva S. Data tersebut akan dikelola ke dalam database MySQL. Bahasa pemrograman yang digunakan pada penelitian ini menggunakan pemrograman PHP dengan menggunakan framework Laravel.

Penelitian mengenai proses monitoring dan evaluasi telah banyak dilakukan, berikut contoh penelitian terkait yang pernah dikembangkan dalam berbagai kasus termasuk dalam tatanan pemerintahan.

Penelitian yang berjudul Sistem Informasi Geografis Monitoring Dan Evaluasi Proyek Dinas Pekerjaan Umum Kota Kotamobagu yang dilakukan oleh Dadang $\mathrm{H}$. Makalalag, Yaulie Deo Y. Rindengan dan Rizal Sengkey [2] membahas mengenai permasalahan kesulitan Dinas PU dalam pemantauan dan mengevaluasi proyek yang sedang proses pengerjaan maupun sudah selesai pengerjaannya. Pengawasan proyek yang dilakukan sebelumnya adalah mengawasi proyek satu persatu secara manual, dikarenakan Dinas Pekerjaan Umum (PU) belum memiliki sistem yang bisa memantau, mengevaluasi kegiatan proyek secara bersamaan dan memberikan gambaran lokasi geografis proyek. Pada setiap proyek yang dikerjakan juga memiliki kendala dan tingkat keberhasilan yang berbeda-beda. Solusi yang dilakukan adalah dengan membangun Sistem Informasi Geografis untuk monitoring dan evaluasi proyek dinas. Dengan adanya Sistem Informasi Geografis ini dapat mempermudah Dinas Pekerjaan Umum Kota Kotamobagu melakukan monitoring serta mengevaluasi proyek yang ada.

Pada artikel peneliti Lis Suryadi [3] yang berjudul Rancang Bangun Sistem Informasi Monitoring Pelaksanaan Pekerjaan Studi Kasus: Suku Dinas Pekerjaan Umum Tata Air Kota Administrasi Jakarta Selatan Dengan Metodologi Berorintasi Obyek telah membahas mengenai permasalahan mengenai proses monitoring pelaksanaan pekerjaan. Permasalahan yang terjadi adalah pengolahan data masih manual dan terkadang kekurangan sumber informasi yang tepat. Kebutuhan laporan yang cepat dan akurat terhambat proses pembuatan laporan tersebut masih dengan cara manual, kurangnya sumber daya manusia yang memadai untuk mengawasi pelaksanaan pekerjaan yang ada, lokasi pekerjaan yang terpencar dan jauh dari lokasi kantor sehingga waktu terbuang hanya untuk meninjau pelaksaan pekerjaan. Solusi yang dilakukan adalah dengan merancang dan membangun sistem informasi monitoring pelaksanaan pekerjaan berbasis pada web untuk dinas tersebut.

Penelitian terkait yang dilakukan oleh Nur Ahsani Maghroh [4], Adiwarman P Paputungan dan Yaulie Deo Y Rindengan [5], M. Tajuddin dan A. Manan [6], Chrisantus Tristianto [7], Amborowati, Armadyah dan Robert Marco [8] dan Muhammad Irsan [9] merupakan penelitian yang melakukan monitoring dan evaluasi pada kegiatan yang dilaksanakan oleh pemerintah.

Kurva S dibuat pada saat perencanaan suatu pekerjaan. Literatur terkait pemanfaat Kurva $\mathrm{S}$ sebagai indikator kemajuan pada suatu pekerjaan telah dibahas pada sebuah penelitian yang berjudul Perbandingan Penjadwalan Proyek Menggunakan Kurva "S" dan CPM Network pada Proyek "X" di Surabaya [10]. Penelitian lain yang membahas terkait dengan Kurva S diantaranya penelitian yang ditulis oleh Amani, Wahyu, Beni Irawan, Helmi [11], Sugoro, Pandu, M. Hamzah Hasyim dan Saifoe El Unas [12], Agustiar, Irawan, dan Ryan Handrianto [13] dan Aritomo, Hendricus [14].

\section{METODOLOGI}

Metodologi penelitian yang diterapkan mengacu pada tulisan A Design Science Research Methodology for Information Systems Research [12]. Pada Gambar 1 merupakan alur penelitian yang digunakan sebagai acuan penelitian.

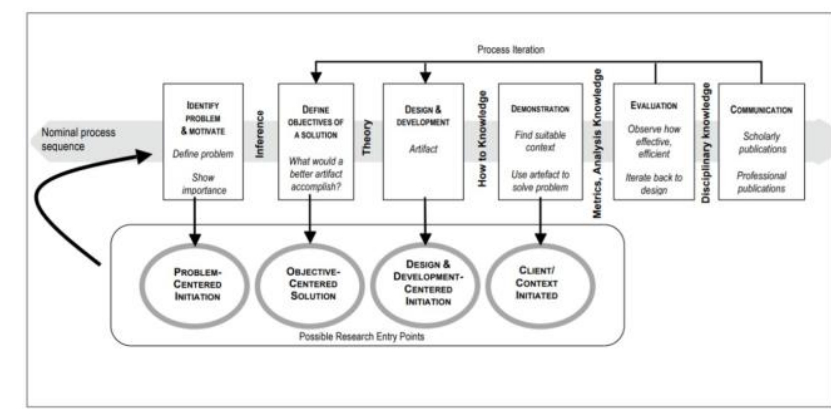

Gambar. 1 A design science research methodology for information systems research

\section{A. Problem Identification and Motivation}

Pada tahap mengumpulkan data dan mewawancarai para pemangku keputusan untuk mengetahui permasalahan yang ada. Merujuk pada permasalahan yang ada maka dilakukan analisa mengenai permasalahan yang terjadi.

\section{B. Objective of the Solution}

Penentuan tujuan dan solusi akan dilakukan secara bersama-sama dengan pemangku keputusan sehigga diharapkan dapat menemukan tujuan dan solusi yang disepakati. 


\section{Design and Development}

Proses analisis terhadap sistem yang akan dikembangkan akan dilakukan pada tahap ini. Analisis sistem akan ditulis dalam bentuk dokumen analisis dapat bentuk diagram UML. Setelah proses analisis selesai maka diakukan proses pembangunan sistem dengan bahasa pemrograman yang sudah ditentukan.

\section{Demonstration}

Pada tahap ini dilakukan demontrasi hasil pekerjaan yang berupa sistem kepada para pemangku keputusan kemudian diberikan masukan terhadap sistem yang telah dibangun. Saran yang diberikan oleh pemangku keputusan akan menjadi perbaikan terhadap sistem.

\section{E. Evalution}

Pada tahap evaluasi dilakukan pengukuran seberapa baik sistem telah dapat menyelesaikan permasalahan yang ada, proses ini akan dilakukan dengan menggunakan kuesioner. Pengujian metode blackbox digunakan untuk melakukan pengujian pada semua proses yang ada pada sistem. Pengujian dilakukan pada proses input data dan menampilkan laporan yang dibutuhkan. Pengujian tahap berikutnya menggunakan metode User Acceptance Test. Pengujian ini dilakukan bersama para pemangku keputusan untuk mengetahui akan sistem yang dikembangkan sudah sesuai dengan alur bisnis yang dibutuhkan.

\section{F. Communication}

Proses komunikasi dilakukan untuk keberlangsungan penggunaan aplkasi. Komunikasi dilakukan dengan mengadakan pelatihan untuk penggunaan sistem.

\section{HASIL DAN PENGUJIAN}

Hasil dari penelitian ini terdiri 3 bagian yaitu Diagram Usecase, Rancangan Database, dan Tampilan Antarmuka. Untuk pengujian akan berbentuk tabel dari hasil pengujian menggunakan metode blackbox.

\section{A. Diagram Usecase}

Diagram usecase mempresentasikan fungsionalitas yang akan dikembangkan pada sebuah sistem. Satu buah usecase merupakan penggambaran interaksi antara sistem dengan aktor. Aktor merupakan entitas berupa manusia atau mesin yang melakukan interaksi dengan sistem untuk melakukan fungsi tertentu.

Pada Gambar 2 terlihat ada 3 orang aktor yaitu Guest, Admin dan Superman. Semua aktor pada sistem ini diharuskan melakukan login. Namun pada diagram tidak digambarkan usecase login. Ketiga aktor tersebut melakukan inheritance, sehingga hak akses Guest juga dimiliki oleh Admin dan hak akses admin dimiliki oleh Superman.

\section{B. Rancangan Diagram Database}

Dari analisis yang telah dilakukan maka menghasilkan rancangan diagram database. Rancangan ini akan menjadi tempat mengelola data dari sistem yang akan dikembang- kan. Pada Gambar 3 terlihat rancangan diagram database yang telah dibuat.

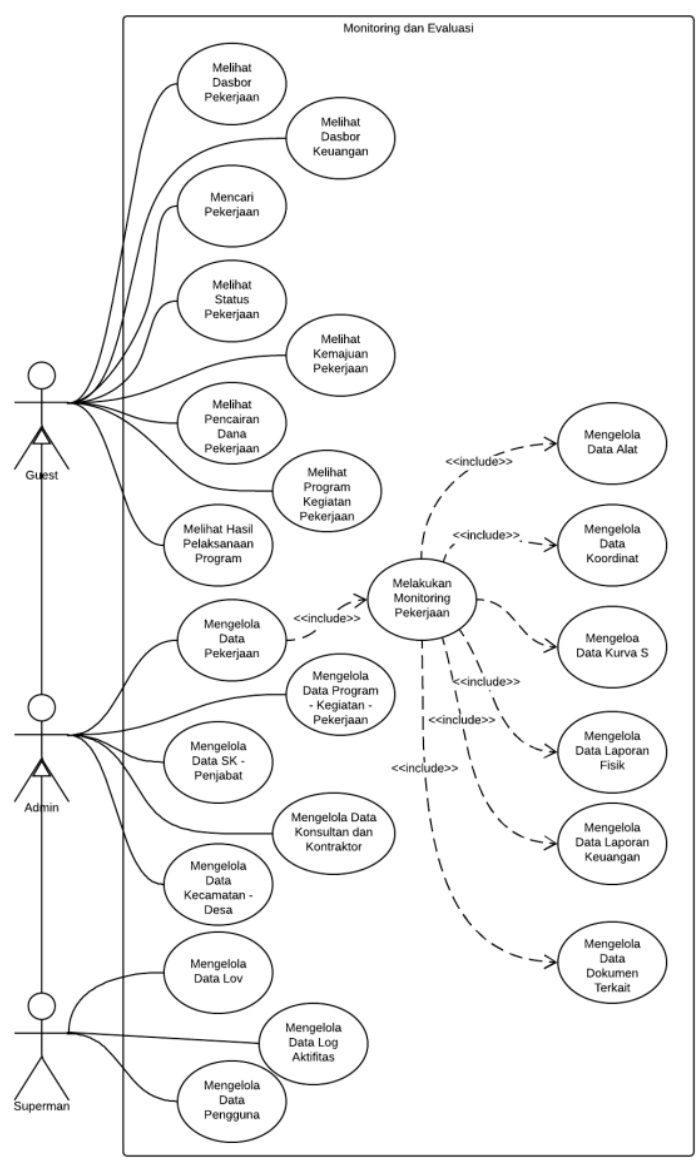

Gambar. 2 Diagram usecase monitoring dan evaluasi pekerjaan
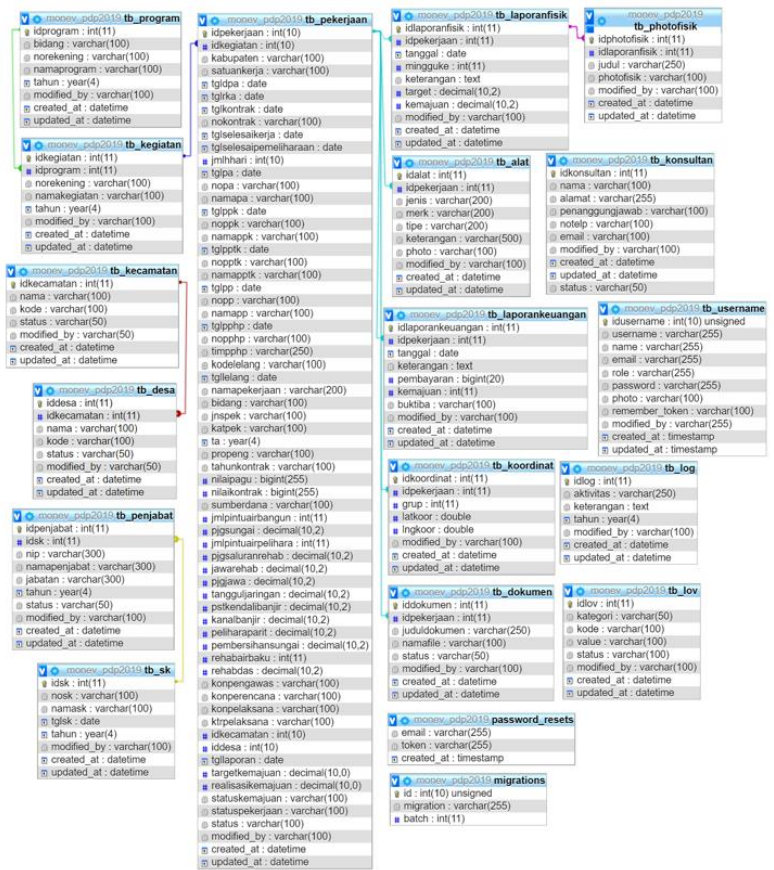

Gambar. 3 Rancangan database monitoring dan evaluasi pekerjaan. 


\section{Rancangan Tampilan Antarmuka}

Perancangan tampilan antarmuka untuk sistem yang dikembangkan. Rancangan ini berbasis pada diagram usecase yang telah dibuat sebelumnya. Rancangan yang dikembangkan berupa purwa rupa sistem. Purwarupa sistem ini sudah dapat digunakan layak sistem yang sudah jadi. Purwarupa sudah terkoneksi dengan database dan memiliki fitur untuk menambahkan, mengedit, menghapus serta sudah dapat menampilkan laporan-laporan yang diperlukan.

Pada Gambar 4 merupakan tampilan halaman untuk pengguna menuliskan username dan password, setelah itu sistem akan melakukan pengecekan kebenaran dari username dan password yang dimasukkan lalu menentukan level aktor dari username tersebut.

Pada Gambar 5 merupakan tampilan ringkasan dari pekerjaan yang dilaksanakan yang berkaitan dengan status pekerjaan tersebut.

Pada Gambar 6 merupakan tampilan ringkasan dari pekeraan yang dilaksanakan yang berkaitan dengan pembiayaan pekerjaan tersebut.

Pada Gambar 7 merupakan tampilan untuk pencarian data pekerjaan yang terdapat di dalam sistem. Proses pencarian ini dilakukan dengan menuliskan kata yang dicari pada kolom isian pencarian data.

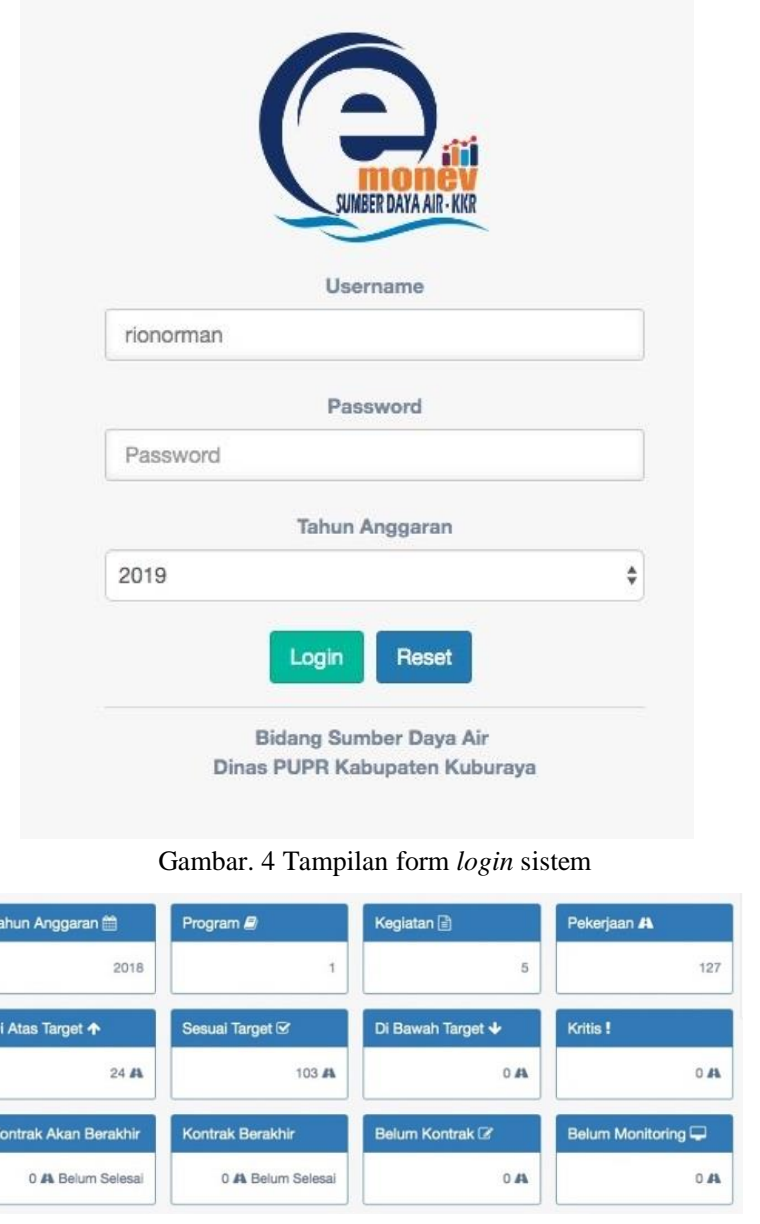

Gambar. 5 Tampilan dashboard pekerjaan

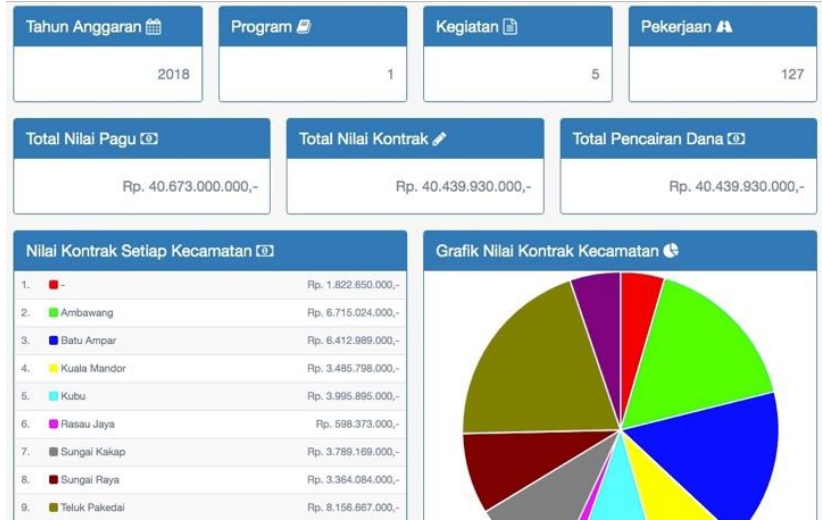

Gambar. 6 Tampilan dashboard pekerjaan

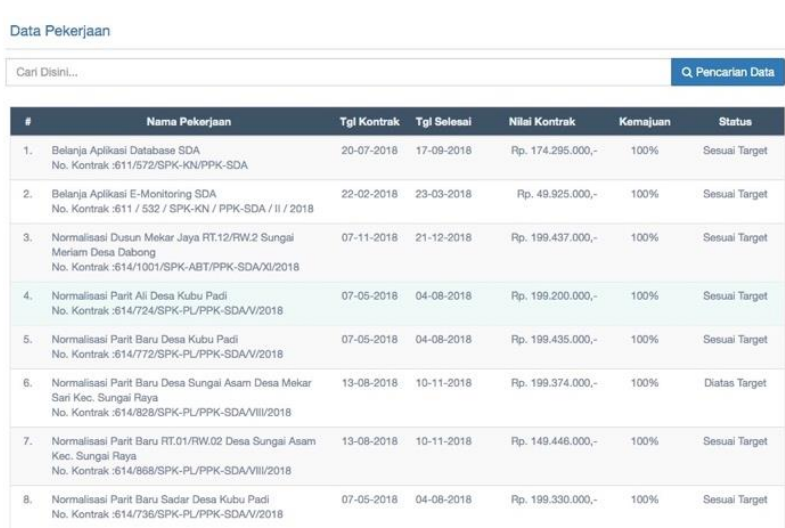

Gambar. 7 Tampilan pencarian data pekerjaan

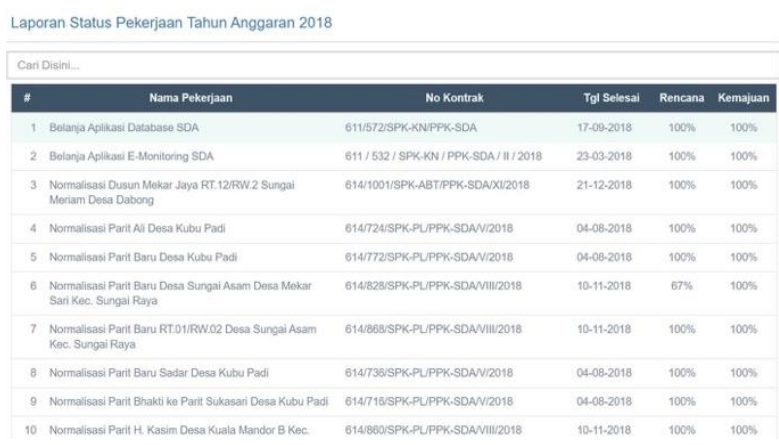

Gambar. 8 Tampilan laporan status pekerjaan

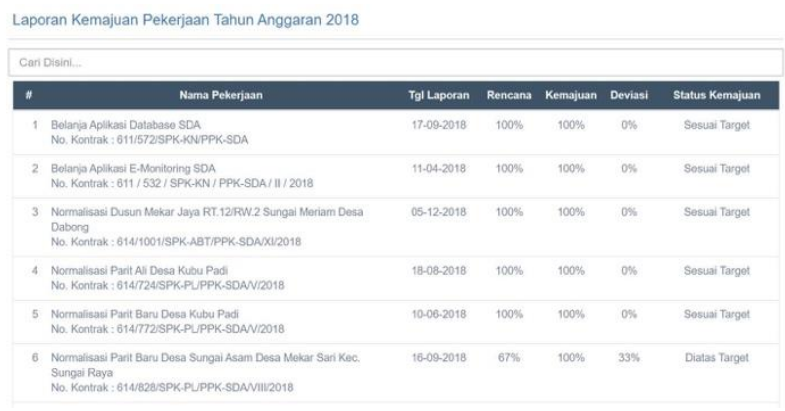

Gambar. 9 Tampilan laporan kemajuan pekerjaan 


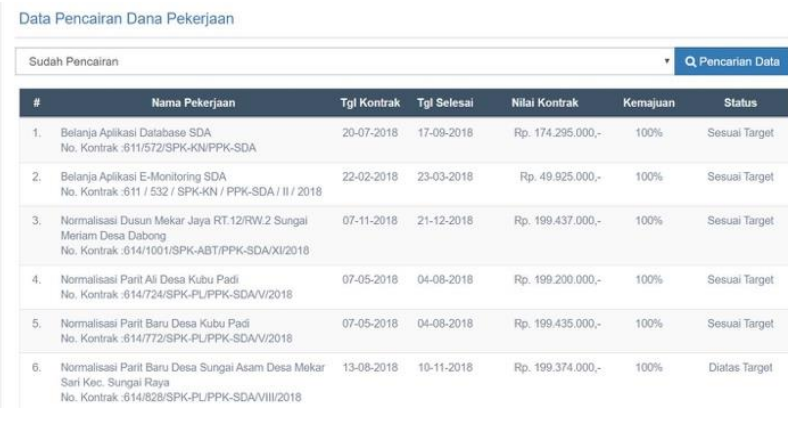

Gambar. 10 Tampilan data pencairan dana pekerjaan

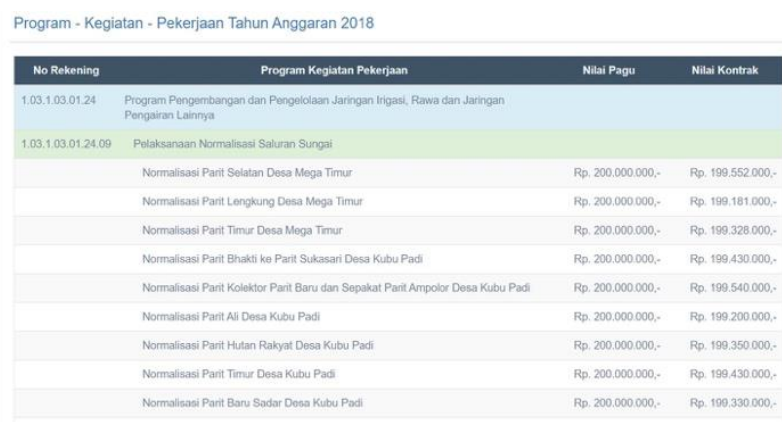

Gambar. 11 Tampilan program kegiatan pekerjaan

Pada Gambar 8 merupakan tampilan laporan dari status pekerjaan. Halaman ini memberikan informasi nama pekerjaan, kapan pekerjaan selesai, presentase rencana dan kemajuaan pertanggal halaman ditampilkan.

Pada Gambar 9 merupakan tampilan halaman menampilkan status kemajuan pekerjaan. Pada tampilan terdapat kolom rencana dan kemajuan. Sistem akan mengecek pada tanggal halaman dibuka berapa persentase kemajuan pekerjaan. Persentase ini kemudian dibandingkan dengan kemajuan yang harus dicapai. Hasilnya ditampilkan pada kolom deviasi. Jika deviasi bernilai negatif maka baris akan berwarna merah

Pada Gambar 10 merupakan tampilan halaman yang memberikan informasi mengenai berapa nilai dana yang telah dikeluarkan untuk pekerjaan sampai dengan tanggal halaman dibuka.

Pada Gambar 11 merupakan tampilan halaman yang memberikan informasi Program, Kegiatan dan Pekerjaan yang dilaksanakan pada tahun berjalan. Terlihat pula kolom nilai pagu dan nilai kontrak. Nilai pagu adalah nilai yang dianggarakan oleh pemerintah sedangkan nilai kontrak adalah nilai sesungguhnya pekerjaan ini dilaksanakan oleh pihak ke-3.

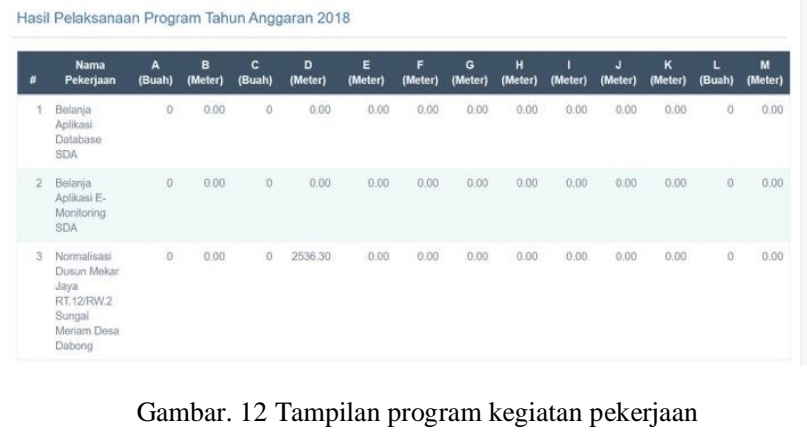

Pada Gambar 12 merupakan tampilan halaman yang memberikan informasi mengenai hasil pekerjaan yang terkait pada pembangunan tertentu.

Pada Gambar 13 merupakan form itu mengelola data pekerjaan yang terdapat pada sistem. Kelengkapan data yang dikelola pada form pekerjaan ini dapat di lihat tabel tb_pekerjaan pada Gambar 3.

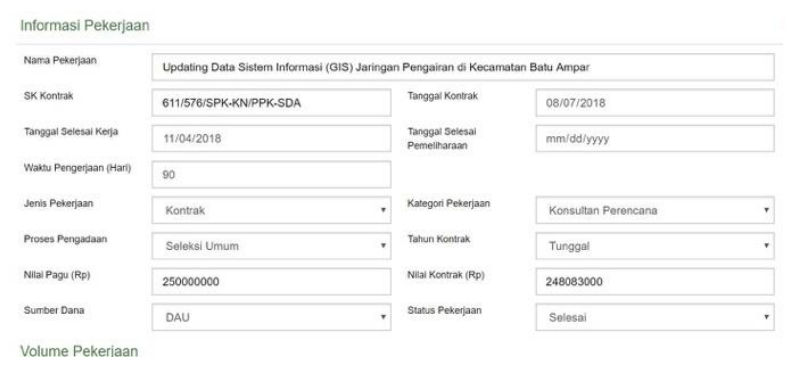

Gambar. 13 Tampilan mengelola pekerjaan

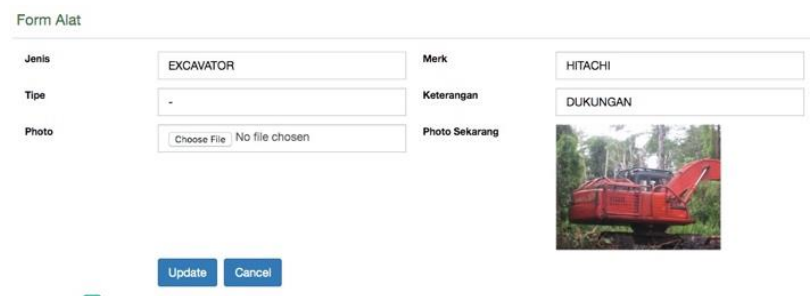

Gambar. 14 Tampilan mengelola alat pekerjaan

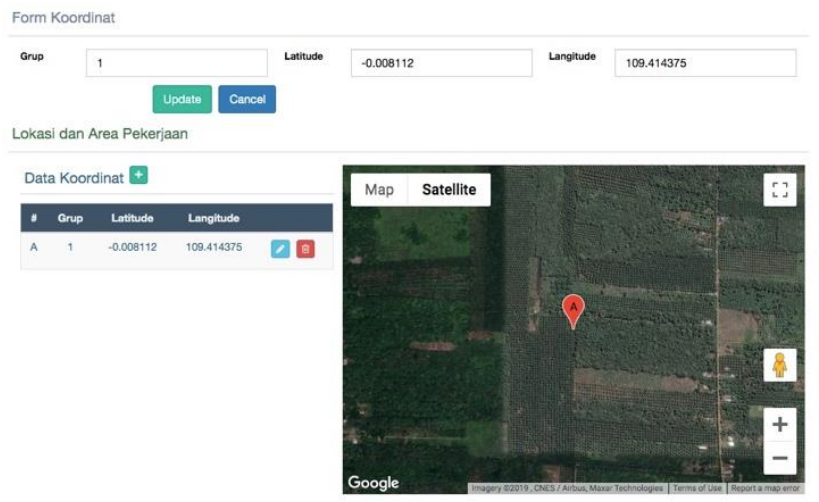

Gambar. 15 Tampilan mengelola koordinat pekerjaan 


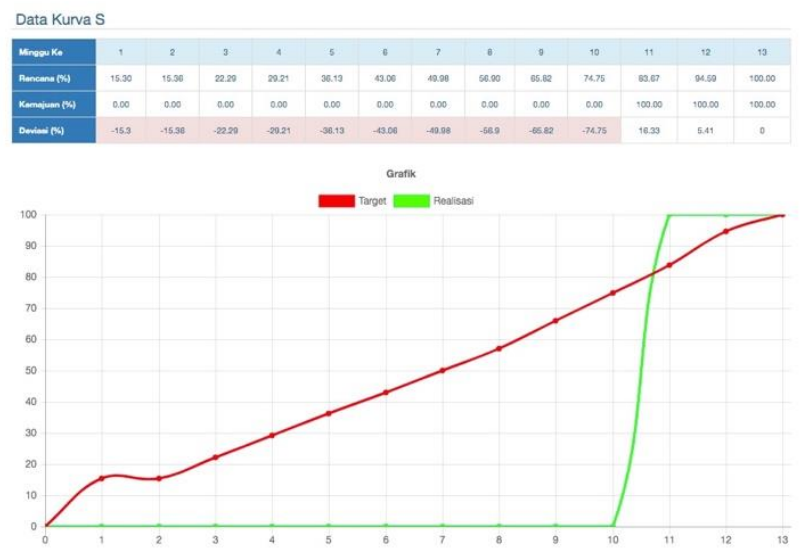

Gambar. 16 Tampilan kurva S dan grafik kemajuan pekerjaan

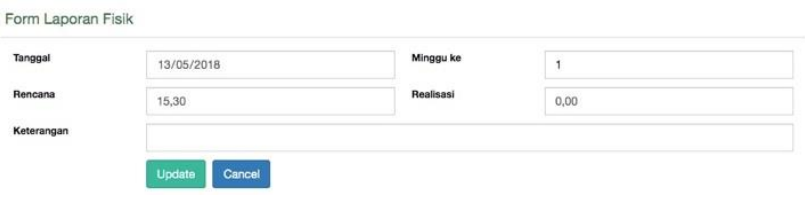

Gambar. 17 Tampilan mengelola presentase kemajuan pekerjaan

Gambar 14, Gambar 15, Gambar 16, Gambar 17, Gambar 18 dan Gambar 19 merupakan bagian proses monitoring dana evaluasi terhadap pekerjaan yang dilaksanakan. Fungsi dari masing-masing form sesuai dengan judul pada setiap Gambar. Detail untuk setiap detail form dapat dilihat pada tabel yang sesuai pada Gambar 3.

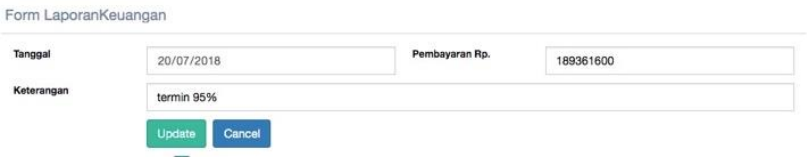

Gambar. 18 Tampilan mengelola pencairan dana keuangan pekerjaan

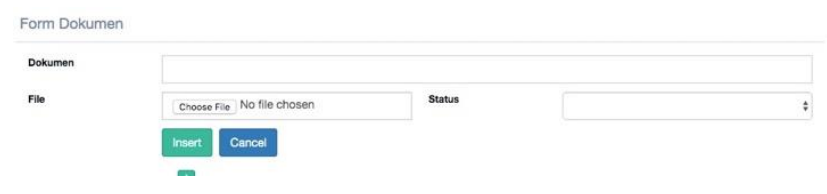

Gambar. 19 Tampilan mengelola dokumen terkait pekerjaan

Gambar 20 merupakan form untuk mengelola data kecamatan sedangkan Gambar 21 merupakan form untuk mengelola data desa.

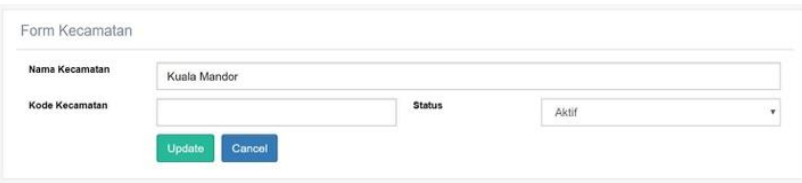

Gambar. 20 Tampilan mengelola data kecamatan

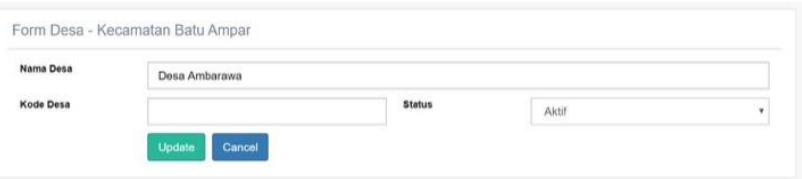

Gambar. 21 Tampilan mengelola data desa

Perancangan antarmuka ini sudah dikembangkan dengan menggunakan teknologi web sehingga dapat diakses dari mana saja baik dengan media computer atau smartphone.

\section{Pengujian}

Pengguna dari sistem ini terbagi menjadi 3 tingkatan yaitu Guest, Admin, dan Superman. Tingkatan Guest merupakan tingkatan terendah yang dapat berinteraksi dengan sistem ini. Guest hanya bisa melihat laporan dan data saja. Tingkatan Guest diberikan kepada para pejabat dinas seperti Kepala Dinas, Kepala Bidang, dan staf ASN Bidang SDA. Tingkatan yang kedua adalah Admin. Para operator memiliki tingkatan ini. Operator pada sistem ini adalah pegawai honor di bidang Sumber Daya Air Dinas PU Kabupaten Kuburaya yang berjumlah 4 orang. Operator memiliki tanggung jawab yang besar terhadap sistem ini. Tugas utama operator adalah memasukkan data yang diberikan oleh konsultan pengawas ke dalam sistem. Adapun tingkatan Superman pada sistem ini adalah Kepala Seksi Perencanaan. Tugas utama Superman adalah mengelola pengguna sistem ini dan menentukan tingkatan dari setiap pengguna.

Pengujian pada sistem yang dikembangkan telah dilakukan pengujian dengan 2 metode yaitu blackbox dan User Acceptance Test (UAT). Metode yang digunakan

Metode blackbox bertujuan untuk melakukan pengujian pada semua proses yang ada pada sistem. Pengujian ini dilakukan pada beragam jenis komputer dan smartphone dengan berbagai speksifikasi mesin yang berbeda-beda untuk menguji performa sistem. Hasil pengujian teknis menunjukkan semua fungsi berjalan dengan baik pada berbagai laptop (Macbook Pro 2011, Macbook Pro 2018, Thinkpad X230, Lenovo Ideapad), komputer (Think Centre M Series) dan smartphone (Oppo F1S, Samsung Galaxy Note 8). Pada Tabel 2 menujukkan hasil dari pengujian blackbox. Pengujian ini mendapatkan hasil 100\%, apabila ditemukan bug pada sistem maka langsung dilakukan perbaikan dan pengujian ulang.

Pengujian ini dilakukan oleh operator pada saat memasukkan data ke dalam sistem. Data yang dimasukkan meliputi data pekerjaan, data alat yang digunakan, data laporan fisik berupa persentase pekerjaan serta photo, data laporan keuangan dan data dokumen terkait pada pekerjaan.

TABEL III

REKAPITULASI PENGUJIAN BLACK BOX

\begin{tabular}{|c|l|c|}
\hline No. & \multicolumn{1}{|c|}{ Item Uji } & Hasil Uji \\
\hline 1. & Melihat Dasbor Pekerjaan & Berhasil \\
\hline 2. & Melihat Dasbor Keuangan & Berhasil \\
\hline 3. & Mencari Pekerjaan & Berhasil \\
\hline 4. & Melihat Status Pekerjaan & Berhasil \\
\hline
\end{tabular}




\begin{tabular}{|c|l|l|}
\hline 5. & Melihat Kemajuan Pekerjaan & Berhasil \\
\hline 6. & Melihat Pencairan Dana Pekerjaan & Berhasil \\
\hline 7. & Melihat Program Kegiatan Pekerjaan & Berhasil \\
\hline 8. & Melihat Hasil Pelaksanaan Program & Berhasil \\
\hline 9. & Mengelola Data Pekerjaan & Berhasil \\
\hline 10. & Melakukan Monitoring Pekerjaan & Berhasil \\
\hline 11. & Mengelola Data Alat & Berhasil \\
\hline 12. & Mengelola Data Koordinat & Berhasil \\
\hline 13. & Mengeloa Data Kurva S & Berhasil \\
\hline 14. & Mengelola Data Laporan Fisik & Berhasil \\
\hline 15. & Mengelola Data Laporan Keuangan & Berhasil \\
\hline 16. & Mengelola Data Dokumen Terkait & Berhasil \\
\hline 17. & Mengelola Data Kecamatan - Desa & Berhasil \\
\hline 18. & Mengelola Data Lov & Berhasil \\
\hline 19. & Mengelola Data Log Aktifitas & Berhasil \\
\hline 20. & Mengelola Data Pengguna & Berhasil \\
\hline
\end{tabular}

Metode pengujian berikutnya adalah pengujian tingkat penerimaan pengguna / user acceptance test (UAT). Pengguna yang dimaksud dalam hal ini adalah para pemangku keputusan di dinas ini. Pemangku keputusan telah memahami alur bisnis yang telah dilakukan saat tidak menggunakan sistem. Kepahaman inilah yang menjadi dasar melakukan UAT dengan para pemangku keputusan. Adapun tujuan pengujian ini adalah sebagai berikut:

1. Untuk mengkonfirmasi bahwa sistem telah melakukan alur bisnis sesuai dengan kebutuhan.

2. Untuk mengkonfirmasi bahwa sistem telah dapat digunakan oleh para pengguna sistem.

3. Untuk mengkonfimasi bahwa sistem telah sesuai dengan persyaratan peraturan yang berlaku.

4. Untuk menjamin bahwa sistem telah dianggap layak untuk digunakan.

Pengujian pada sistem dilakukan dengan menggunakan metode pengukuran skala likert menggunakan kuesioner. Kuisinoner diisi oleh 4 orang responden. Keempat responden tersebut adalah Kepada Bidang, Kepala Seksi dan 2 orang staf ASN di bidang Sumber Daya Air. Pada Tabel 3 menunjukkan rekapitulasi dari responden.

TABEL IIIII

ReKaPitulasi PENGUJian USER ACCEPTANCE TEST

\begin{tabular}{|c|l|c|c|c|c|c|}
\hline No & \multicolumn{1}{|c|}{ Unsur Penilaian } & SS & S & N & TS & STS \\
\hline 1 & $\begin{array}{l}\text { Sistem telah sesuai dengan } \\
\text { fungsi bisnis? }\end{array}$ & $75 \%$ & $25 \%$ & $0 \%$ & $0 \%$ & $0 \%$ \\
\hline 2 & $\begin{array}{l}\text { Sistem telah dapat } \\
\text { digunakan oleh para } \\
\text { pengguna sistem? }\end{array}$ & $100 \%$ & $0 \%$ & $0 \%$ & $0 \%$ & $0 \%$ \\
\hline 3 & $\begin{array}{l}\text { Sistem telah sesuai dengan } \\
\text { persyaratan peraturan yang } \\
\text { berlaku? }\end{array}$ & $100 \%$ & $0 \%$ & $0 \%$ & $0 \%$ & $0 \%$ \\
\hline 4 & $\begin{array}{l}\text { Sistem telah dianggap layak } \\
\text { untuk digunakan? }\end{array}$ & $75 \%$ & $25 \%$ & $0 \%$ & $0 \%$ & $0 \%$ \\
\hline
\end{tabular}

Rekapitulasi pengujian menunjukkan sebagian besar (75\%) responden sangat setuju bahwa sistem sudah sesuai dengan alur bisnis, seluruh responden (100\%) sangat setuju sistem telah dapat digunakan oleh para pengguna, seluruh responden (100\%) sangat setuju sistem telah sesuai dengan peraturan yang berlaku dan sebagian besar responden (75\%) sangat setuju sistem telah dianggap layak untuk digunakan.

\section{KESIMPULAN}

Dengan adanya sistem informasi monitoring dan evaluasi pekerjaan ini dapat memberikan informasi terbaru dan cepat kepada pihak bidang SDA Dinas PU Kabupaten Kuburaya. Para pemangku jabatan dapat mengakses informasi yang diperlukan tanpa harus bertanya kepada bawahannya. Pengumpulan data pada sistem ini tentu saja menambah kecepatan dalam penyajian data. Bahkan pekerjaan yang di pelosok kabupaten dapat diketahui dengan akurat kemajuannya berkat pelaporan dalam bentuk foto pada sistem ini.

Metode pengujian black box menunjukkan semua proses yang telah dirancang bisa berjalan dengan baik untuk perangkat dengan berbagai spesifikasi mesin. Hasil pengujian User Acceptance Test menunjukkan 75\% responden menyatakan sistem sesuai dengan alur bisnis dan $75 \%$ sangat setuju bahwa sistem layak untuk digunakan. Unsur penilaian lain yaitu sistem telah dapat digunakan dan telah sesuai dengan persyaratan yang berlaku mendapat respon dari responden senilai $100 \%$.

\section{REFERENSI}

[1] Peraturan Pemerintah Republik Indonesia Nomor 19 Tahun 2005 , Tahapan, Tata Cara Penyusunan, Pengendalian dan Evaluasi Pelaksanaan Perencanaan Pembangunan Daerah. 4 Februari 2008 Lembaran Negara Republik Indonesia Tahun 2008 Nomor 21. Jakarta

[2] D. H. Makalalag, Y. Rindengan, and R. Sengkey, Sistem informasi geogras monitoring dan evaluasi proyek dinas pekerjaan umum kota-kota mobagu. Jurnal Teknik Informatika, vol. 9, no. 1, 2016

[3] L. Suryadi, Rancang Bangun Sistem Informasi Monitoring Pelaksanaan Pekerjaan Studi Kasus: Suku Dinas Pekerjaan Umum Tata Air Kota Administrasi Jakarta Selatan Dengan Metodologi Berorintasi Obyek. SENTIA 2015, vol.7, no. 2, 2017.

[4] N. Maghroh. Efektivitas sistem informasi pelaporan monitoring dan evaluasi (e-controlling) pada bagian evaluasi pembangunan sekretariat daerah kota bontang. Jurnal Paradigma (JP), vol. 5, no. 1, pp. 34-44, 2017.

[5] A. P. Paputungan, Y. Rindengan. Sistem Monitoring Dan Evaluas Anggaran Pendapatan Belanja Daerah (Apbd) Di Kabupaten Bolaang Mongondow Selatan Berbasis Web. Jurnal Teknik Informatika, vol. 11, no. 1, 2017.

[6] M. Tajuddin and A. Manan. Rancang Bangun Sistem Informasi Monitoring Satuan Kerja Dalam Rangka Good Governance. MATRIK: Jurnal Manajemen, Teknik Informatika dan Rekayasa Komputer, vol. 15, no. 1, pp. 35-44, Nov. 2015.

[7] T. Chrisantus. Penggunaan Metode Waterfall Untuk Pengembangan Sistem Monitoring Dan Evaluasi Pembangunan Pedesaan. ESIT, vol. 12, no. 1, 2018.

[8] Amborowati, Armadyah, and R. Marco. Analisis Pengelolaan Dan Monitoring Dana Bantuan Operasional Sekolah (BOS) Menggunakan Sistem Informasi Berbasis Website Pada SLTP Di Daerah Istimewa Yogyakarta. Data Manajemen dan Teknologi Informasi (DASI), vol. 17, no. 1, pp. 6-14, 2016.

[9] I. Muhammad. Rancang bangun aplikasi mobile notifikasi berbasis android untuk mendukung kinerja di instansi pemerintahan. Jurnal Sistem dan Teknologi Informasi (JUSTIN) vo. 3, no. 1, pp. 115120, 2015.

[10] S. Wenly. Perbandingan Penjadwalan Proyek Mengguna-kan Kurva " $S$ " dan CPM Network pada Proyek " $X$ " di Surabaya. JURNAL DIMENSI UTAMA TEKNIK SIPIL 3.2, 2016.

[11] W. Amani, Helmi, dan B. Irawan. Perbandingan Aplikasi CPM, PDM, dan Teknik Bar Chart-Kurva S Pada Optimalisasi Penjadwalan Proyek. BIMASTER 1.01, 2012.

[12] P. Sugoro, M. Hamzah Hasyim, dan S. Unas. Monitoring Pada Pembangunan Proyek Terminal Penumpang Kabupaten Barru Sulawesi Selatan Dengan Metode Konsep Nilai Hasil 
Dikonversikan Terhadap Kurva S. Jurnal Mahasiswa Jurusan Teknik Sipil 1.1: pp-79, 2015.

[13] I. Agustiar, dan R. Handrianto. EVALUASI PENJADWALAN PROYEK MENGGUNAKAN METODE CPM DAN KURVA S. Wahana Teknik 7.2, 2018
[14] H. Aritomo, Evaluasi proyek pembangunan gedung kantor pusat PT Lautan Luas Tbk. berdasarkan kurva S. Diss. Universitas Gadjah Mada, 2001.

[15] K. Peers, T. Tuunanen, M. Rothenberger, and S. Chatterjee, " $A$ design science research methodology for information systems research. Journal of management information systems", vol. 24, no. 3, pp. 45-77, 2007. 